\title{
Laporan harian/mingguan
}

Minggu ke-4

\section{( Pembuatan Tempat Sampah, Pengajaran TK TPA dan Jumat Bersih )}

\author{
Nama : jusniati \\ Posko : Tolo' Timur \\ Tempat Kegiatan : Kelurahan Tolo' Timur \\ Nim : 9173490410027 \\ Email : bungengjusniati@gmail.com
}

1. Bentuk kegiatan

Pembuatan tempat sampah, pengajaran TK-TPA dan jumat bersih.

2. Lokasi

Untuk mesjid, lapangan, kantor lurah dan Masjid Nurul Falaq

3. Hari/tanggal dan waktu

- Pembuatan tempat sampah tanggal 5-8 oktober 2020

- Pengajaran TK-TPA tanggal 6 , 7, 8, dan 9 oktober 2020

- Jumat bersih 9 oktober 2020

4. Peserta yang dilibatkan

Peserta KKLP STIE/STKIP YAPTI JENEPONTO angkatan XXII tahun akademik 2020/2021, pemuda karang taruna tolo timur dan Santri masjid Nurul falaq

5. Alasan di adakannya

- Agar masyarakat tidak membuang sampah sembarang tempat

- Pengajaran TK TPA untuk mengajar mengaji dan mengenal serta memahami huruf hijaiyah di Masjid nurul falaq

- Jumat bersih agar mesjid terlihat bersih dan nyaman saat beribadah

6. Tujuan dan manfaat

- Pembuatan tempat sampah ini sangat bermanfaat agar sampah tidak berceceran di sembarang tempat.

- Pengajaran TK TPA bertujuan untuk mengajarkan ke pada 
santri tentang ilmu agama islam dan pentingnya islam dalam kehidupan

- Jumat bersih bertujuan untuk membersihkan serta menarik perhatian masyarakat untuk mengetahui betapa pentingnya kebersihan terutama di mesjid yang merupakan tempat ibadah kita.

\section{Deskripsi kegiatan}

Kami peserta KKLP yang dibantu pemuda karang taruna tolo timur dalam pembuatan tempat sampah yang akan di sebar di mesjid-mesjid, lapangan dan kantor lurah. 